\title{
Effect of Different Storage Methods on Development of Post-Harvest Rot of Solanum tuberosum L. in Yola, Adamawa State Nigeria
}

\author{
Hamidu Musa Yoldere \\ Department of Integrated Science, School of Sciences, Federal College of Education, Yola, Adamawa state, \\ Nigeria
}

\begin{abstract}
Investigation into the effects of different storage methods on the development of post-harvest rot of Irish potato [Solanum tuberosum (L.)] were carried out in the Biological Sciences Laboratory of Modibbo Adama University of Technology, Yola using completely Randomized Design (CRD). Two thousand grammes of healthy Irish potato tubers were stored in ' $A$ ' medium-sized $(35 \times 30 \times 23 \mathrm{~cm})$ perforated plastic basin and covered with chaff of guinea corn, in ' $\mathrm{B}$ ' the potatoes were smeared with $2.0 \mathrm{~g}$ of wood ash and kept in $(35 \times 30 \times 23 \mathrm{~cm})$ perforated plastic basin, in ' $C$ ' the potatoes were kept in a medium size $(38 \times 25 \times 18 \mathrm{~cm})$ box, in ' $D$ ' the potatoes were heaped on a clean floor and covered with $30 \mathrm{~cm}$ rice straw with a ventilating duct, in ' $\mathrm{E}$ ' they were stored underground $(20 \times 30 \mathrm{~cm})$ hole and lastly ' $F$ ' the potatoes were left on the ground which served as control (untreated). Data were collected every week for six weeks on percent weight loss and rot development, the data obtained were analyzed using Analysis of Variance (ANOVA) and the means that were significant were separated using the Least Significant Difference (LSD). Results showed that wood ash provided the best storage medium with a weight loss of $43 \mathrm{~g}$. This is followed by straw which recorded $53 \mathrm{~g}$ and the highest was the storage in box with $110 \mathrm{~g}$ weight loss. On rot development wood ash also proved most effective with a least mean value of $56 \mathrm{~g}$, followed by rice straw $122 \mathrm{~g}$, while underground storage was the least with $322 \mathrm{~g}$. Analysis of variance showed significance differences among the various treatments. Storage of Solanum tuberosum tubers in wood ash and rice straw are the most suitable control measure.
\end{abstract}

Keywords: Solanum tuberosum, weight loss, rot development, rice straw, guinea corn chaff and wood ash.

DOI: $10.7176 / \mathrm{JBAH} / 9-4-03$

\section{Introduction}

Potato (Solanum tuberosum L.) is a dicotyledonous plant belonging to the Solanaceae family (Dutta, 2005). It is cultivated in temperate and subtropical regions across the world (Vaughan and Geissler, 2009). It is the most important vegetable crop of the world, ranking number one among all vegetables both in production and consumption (Abbas et al., 2011). It is widely cultivated for its edible tubers which are used to produce a variety of products including chips, crisps, (Leeman et al., and 2008), vegetable relish/salad, canning and livestock feed (Abbas et al., 2011). It contains high crude protein than any other root and tuber crop because of the low colorie and high vitamin C content and can be regarded as an important nutritive food (Burton, 1966). It has become an integral part of much of the world cuisine and is the fourth largest yielding crop in the world after wheat, rice and maize (FAOSTAT, 2008).

It contributes to reducing worldwide food shortages (Han et al., 2005). According to Salazar (1982) the crop is adapted to a cool moist climate, and grows in the high altitudinal ecosystems of Sub-Saharan Africa where rainfall is well distributed for 3-4 months. This entails that potato production can be obtained in many different areas or regions of the world (Carnegie, 2000). Of all primary food crops, potatoes suffer the greatest losses due to disease (Agrios, 1997). It is sensitive to quality loss than cereals because conservation using drying techniques cannot be applied. Loss of moisture leads to quality loss and finally to nonmarketable produce. The risk of unacceptable moisture loss, disease spread, mold infections, and insect pests is obvious (Small and Phal, 2003).

\section{Materials and Methods \\ 2.1 Collection of Samples}

A total of two thousand four hundred samples were collected in Yola town and jimeta markets of Adamawa state located between latitude 9011 ' to $9019^{\prime}$ N and longitude 12020' to 12030' E. Samples of Solanum tuberosum were collected from different selling points randomly in the markets and were taken to the laboratory for studies.

\subsection{Collection and Preparation of Plant Materials/Storage Materials}

Wood ash collected free from domestic burnt of Eucalyptus camaldulensis, rice straw collected from the nearby paddy farm, guinea chaff purchased and empty cardboard box purchased from Jimeta market. Five hundred of each of the plant material/storage materials in four replicates were placed into sterile polyethene bags and taken to the laboratory. 
2.3 Effect of wood ash, guinea corn chaff, rice straw, box and underground storage on Solanum tuberosum Two thousand grammes of healthy Solanum tuberosum were placed in $35 \mathrm{~cm}$ diameter perforated plastic basins labeled 'A", 'B", under $30 \mathrm{~cm}$ rice straw labeled 'C", in a medium size cardboard $(32 \times 30 \times 25 \mathrm{~cm})$ box with a lid or top flaps that can be folded closed labeled " $D$ " and underground (pit) labeled ' $E$ " and empty ground floor labeled " $F$ " as control. Tubers in 'A' were smeared with $2.0 \mathrm{~g}$ of wood ash, in 'B" tubers were covered with guinea corn chaff, in ' $\mathrm{C}$ ' tubers were heaped on sterilized ground floor and covered with $30 \mathrm{~cm}$ rice straw, in ' $\mathrm{D}$ ' tubers were placed in a box with a led that was folded, in 'E" tubers were placed inside a 20x30cm dogged hole and lastly tubers were placed on ground floor without any cover as control. All were arranged in completely randomized designed with four replication at room temperature. The experiment lasted for six weeks. During the storage period data were collected on weight loss, rot development of Solanum tuberosum.Randomized designed was used as describe by Gomez and Gomez (1984) and the experiment were replicated four times. Data gathered were analysed using analysis of variance (ANOVA) and the mean that were significant were separated by least significance difference according to Schiff (1953).

\section{Results}

The result on mean weight loss of Solanum tuberosum tubers stored in wood ash, guinea corn chaff, box, rice straw, underground media for six months period showed that weight loss was significantly ( $p>0.01)$ affected by the treatments shown in table 1. Potato samples stored in wood ash had the lowest average weight loss (43g), while those in control recorded the highest weight loss $(172 \mathrm{~g})$. Generally weight loss of Solanum tuberosum tubers increase with storage period. The treatment mean of rot development of Solanum tuberosum tubers stored in wood ash, guinea corn chaff, box, rice straw, underground media for six months period showed highly significant $(p>0.01)$ effect of the preservatives as compared to control. The highest incidence of rot development $(322 \mathrm{~g})$ was recorded in underground tubers which were significantly different from the other treatments; the lowest incidence of rot development $(56 \mathrm{~g})$ was obtained in tubers treated with wood ash (table 2). Irrespective of storage media rot development increased progressively with time of storage.

\section{Discussions}

Findings of the study showed that storage of Solanum tuberosum tubers in wood ash, guinea corn chaff, box, rice straw and underground was effective compared to the control, although wood ash proved most effective. This agreed with Agbemalfe et al. (2013) who reported that the use of wood ash in storing sweet potatoes gave the best result against other methods with only 5\% percent shrinkage. The present findings also agreed with that of Edward and Christopher (2007) who reported that the use of ash proved to be better in reducing change in weight loss brought about by loss of water from the surface of the potatoes, this is because the ash acts as an absorbent to moisture and has a repelling effect on pests and it also has alkaline properties, which are not conducive to development of most fungi. The study further revealed that rot development was least recorded in tubers stored in wood ash and the highest was in tubers stored underground. This agreed with Akinleye et al (2013) who reported that lowest rot was recorded in tubers stored in the Ash while the highest rot was observed on tubers that were stored with sliced onions. Bristone et al. (2011) also reported that when tubers of sweet potatoes were treated with wood ash, rot caused by R. stolonifer and Penicellium expansum was reduced to minimal level. Similarly, Channya and Chimbekujwo (2002) reported that wood ash effectively controlled fungal rot of plantains (Musa pradisiaca) in Ibadan, Nigeria. The findings also agreed with Edward and Christopher (2007) on the use straw (dry grass) who reported that; dry grass is used to create dry and cool conditions within the storage area and this avoids the development of fungal diseases that normally thrive under humid and warm conditions. The study further revealed that there was increase in weight loss of the tubers with increase storage period. This in agreement with studies carried out by Dandugu and Gungola (2011) who observed that weight loss in stored sweet potatoes increase with storage period. The loss in weight according to Ray and Ravi (2005) could be due to respiration and transpiration, reduction in moisture content.

\section{Conclusion}

This study showed that wood ash, guinea corn chaff, box, rice straw and underground (pit) can serve as storage media for Solanum tuberosum for a period of six weeks, although wood ash gave better result in terms of mean weight loss and rotting. These are effective alternatives for minimizing post-harvest rot.

\section{References}

Abbas, G. K., Frooq, I.A., Hafiz, A., Hussain, N.A. and Abbasi, G. S. (2011). Assessment of Processing and Nutritional Quality of Potato Genotypes in Pakistan. Pakistan Journal of Agriculture Science. 48:169-175.

Agbemafle, R., Sekyere, J.O., Diabor, E. and Essien, J. (2013). Effect of Storing Cream Skinned Potatoes in Wood ash and Saw dust on Physiochemical properties and shelf-life. Journal of Biological Food Resources. 2 (7): $85-91$. 
Agrios, G.N. (1997). Common Scab of Potato. In: Plant Pathology. California, Academic Press, pp. 449-451.

Akinleye, O.M., Buhari. O.A., Adebisi, R.T., Raheem, A. R.R., Makanjuola, S.O. and Oluwadun,A. (2013).Relationship Between Intrinsic Factors And Aetiology of Rot in Irish Potato (Solanum-Tuberosum L.) Purchased In Lagos, Nigeria. New York Science Journal 6 (4): 1-13.

Bristone, B., Chimbekujwo, I.B. and Pukuma, M.S. (2011). Control of Post-harvestFungal Rot of Sweet Potatoes (Ipomoea batats) in Yola. Nigerian Journal of Batany, 24 (1): 43-51.

Burton, W.G. (1966). Nutritive Value of Potato. In the Potato.H. Venman and Zonen N.V. Holland. Pp 23-25.

Channya, F.K. and Chimbekujwo, I.B. (2002). Pathogens of Post-harvest Fruit Rot of Plantain

(Musa paradisiacal b.) in South Western Nigeria. Journal of Tropical Biosciences. 2:12-15.

Carnegie, S.F. (2000). The Effect of Treating Seed Potato Tubers with Benzimidazole, and Phenylpyrrole Fungicides on the Control of Rot and Skin Blemish Diseases. Pp 343-363.

Dandago, M.A. and Gungula, D.T.(2011). Effects of Various Storage Methods on the Quality and Nutritional Composition of Sweet Potato (Ipomea batatas L.) in Yola Nigeria. International Food Research Journal 18: 271-278.

Dutta, A.C (2005). Botany for Degree Students. Eighteenth Edition. Oxford University press. Pp.444-445.

Edward, M. and Christopher, T. G.(2007). Comparative Assessment of Indigenous Methods of Sweet Potatoes Preservation among Small holder Farmers: A case of Grass, Ash and Soil based approaches in Zimbabwe. African Studies Quarterly. 9 (3): 87-98.

Gomez, K.A and Gomez, A.A. (1984). Statistical Procedures for Agricultural Research. John wiley and sons. pp 680.

Han, J.S.,Cheng, J.H.,Yoon, T.M., Song, J., Rajkarnikar, A., Kim, W.G., Yoo, I.D., ang, Y.Y. and Suh, J.W. (2005). Biological Control agent of Common scab Disease By antagonistic strain Bacillus spp. Journal of Applied Microbiology. 99: 213-221.

Leeman, M., Ostman, E. and Bjorck, I. (2008). Glycaemic and Satiating Properties of Potato products. European Journal of Nutrition. 62:87-95.

Ray, C. and Ravi, V. (2005). Post-harvest spoilage of sweet potato in Tropics and Control measures. Critical Reviews in Food Science and Nutrition. 45; 23-64.

Salazar, L.F. (1982). Virus Detection in Seed Potato Production. Technical Information Bulletin N0. 18. CIP, Lima, Peru. P.14

Schiffe, .H. (1953). A method of judging all Contrasts in Analysis of variance. Biometrics, 40; 104-107.

Small, D. and Pahl, K. (2003). Potato Storage Management, Guide to Commercial Potato Production on the Canadian Prairies published by the Western Potato Council. Pp 34-39.

Vaughan, J. G. and Geissler, C. A. (2009). The New Oxford Book of Food Plants. 2nd Edition. Oxford University Press, Oxford, UK.Pp 37-39.

\section{Acknowledgement}

We want thank the department and staff of plant science for allowing the laboratory facilities for the present research.

Table 1: Weight loss (gm) of Solanum tuberosum after six weeks of storage (April-May, 2015)

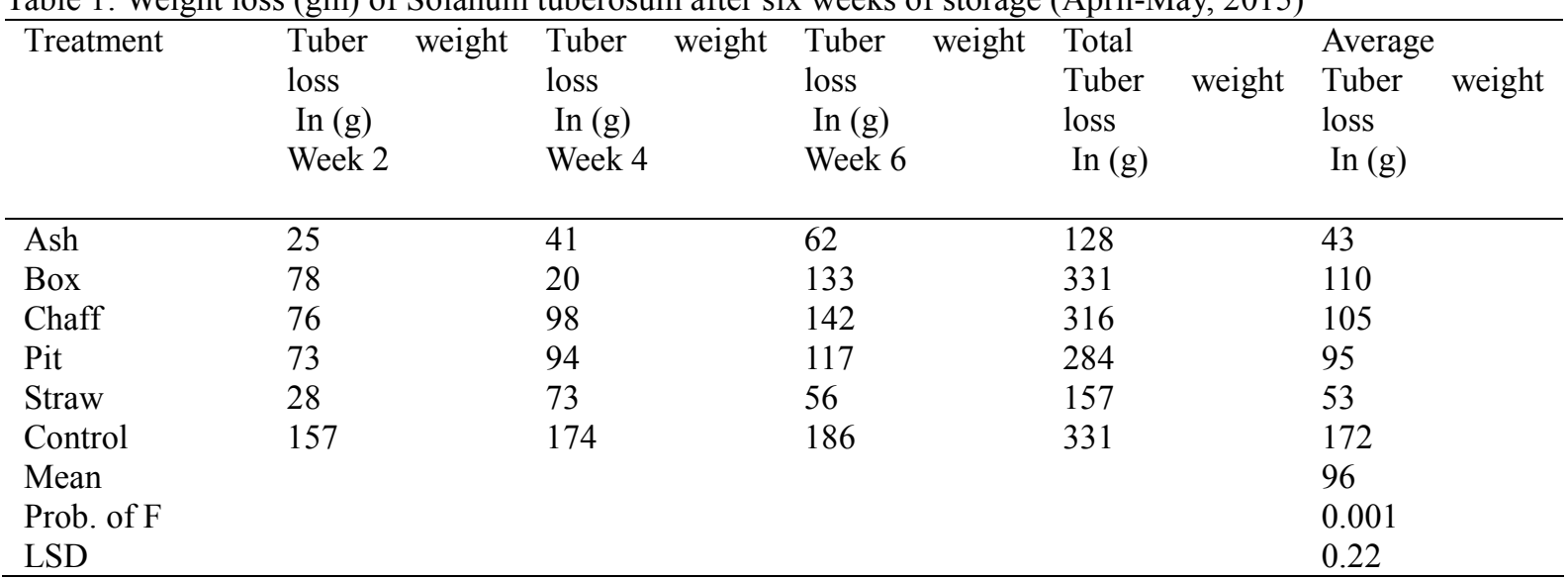


Table 2: Rot development of Solanum tuberosum after six weeks of storage (April-May, 2015)

\begin{tabular}{|c|c|c|c|c|c|c|c|c|c|c|}
\hline \multirow[t]{4}{*}{ Treatment } & \multirow{4}{*}{$\begin{array}{l}\text { Tuber } \\
\text { loss } \\
\text { In }(g) \\
\text { Week } 2\end{array}$} & \multirow[t]{4}{*}{ weight } & \multirow{4}{*}{\multicolumn{2}{|c|}{$\begin{array}{l}\text { Tuber weight } \\
\text { loss } \\
\text { In }(g) \\
\text { Week } 4\end{array}$}} & \multirow{4}{*}{$\begin{array}{l}\text { Tuber } \\
\text { loss } \\
\text { In }(\mathrm{g}) \\
\text { Week } 6\end{array}$} & \multirow[t]{4}{*}{ weight } & \multirow{4}{*}{$\begin{array}{l}\text { Total } \\
\text { Tuber } \\
\text { loss } \\
\text { In }(g)\end{array}$} & \multicolumn{3}{|c|}{ Average } \\
\hline & & & & & & & & weight & Tuber & weight \\
\hline & & & & & & & & & loss & \\
\hline & & & & & & & & & In $(\mathrm{g})$ & \\
\hline Ash & 33 & & 63 & & 71 & & 167 & & 56 & \\
\hline Box & 33 & & 133 & & 300 & & 466 & & 156 & \\
\hline Chaff & 100 & & 167 & & 200 & & 467 & & 156 & \\
\hline Pit & 200 & & 333 & & 433 & & 966 & & 322 & \\
\hline Straw & 67 & & 100 & & 200 & & 367 & & 122 & \\
\hline Control & 267 & & 367 & & 500 & & 113.4 & & 378 & \\
\hline Mean & & & & & & & & & 198 & \\
\hline Prob. Off & & & & & & & & & 0.001 & \\
\hline LSD & & & & & & & & & 0.41 & \\
\hline
\end{tabular}

\section{Brief biography of the author}

My name is Hamidu Musa Yoldere, I was born in Yola town Adamawa state, Nigeria, (in 1976).

I hold or obtained the following qualifications; first degree; BSc.Ed Integrated Science from Ahmadu Belio University, Zaria, Nigeria in 2004. Second degree; M.tech. Plant pathology from Modibbo Adama University of Technology, Yola in 2015 and I am looking forward for third degree (PhD). 